National Marine

Fisheries Service

NOAA
Fishery Bulletin

2o established in $1881 \%$
Spencer F. Baird

First U.S. Commissione of Fisheries and founder of Fishery Bulletin
Abstract-The main objective for this study was to provide information on the relationship between dolphinfish (Coryphaena spp.) catches and the environmental conditions, which could help to explain dolphinfish movements in the eastern tropical Pacific Ocean off the coast of Mexico-a topic that is still under debate. We analyzed a 10 -year (2004-2013) database of estimated incidental catch from the InterAmerican Tropical Tuna Commission, reported by observers on board tuna purse-seine ships. Significant seasonal and interannual differences were found in the incidental catch. No segregation due to size was apparent. Two areas of high catch were present in the study zone: one near the Baja California Peninsula that is especially productive during summer, and a second in an oceanic area $\left(\sim 15^{\circ} \mathrm{N}, 120^{\circ} \mathrm{W}\right)$, which is present all year long but becomes more important during May-June. Using satellite images, we found that the 2 species of dolphinfish preferred warm waters $\left(24-28^{\circ} \mathrm{C}\right)$ with low concentrations of chlorophyll- $a(<0.02 \mathrm{mg} /$ $\mathrm{m}^{3}$ ), and mainly positive values of sea-surface height, all of which suggested that dolphinfish spp. associate with oceanographic features, such as anticyclonic eddies. There was a seasonal SE-NW-NE movement of high incidental catch across survey quadrants $\left(1^{\circ} \times 1^{\circ}\right)$, movement that is closely related to the latitudinal displacement of the $25^{\circ} \mathrm{C}$ isotherm.

Manuscript submitted 25 January 2017. Manuscript accepted 18 October 2017. Fish. Bull. 116:9-20 (2018).

Online publication date: 7 November 2017. doi: $10.7755 /$ FB.116.1.2

The views and opinions expressed or implied in this article are those of the author (or authors) and do not necessarily reflect the position of the National Marine Fisheries Service, NOAA.

\title{
Environmental and spatial preferences of dolphinfish (Coryphaena spp.) in the eastern Pacific Ocean off the coast of Mexico
}

\author{
Emigdio Marín-Enríquez \\ Arturo Muhlia-Melo (contact author) \\ Email address for contact author: amuhlia04@cibnor.mx \\ Centro de Investigaciones Biológicas del Noroeste, Sociedad Civil \\ Avenida Instituto Politécnico Nacional 195 \\ Colonia Playa Palo de Santa Rita \\ 23096 La Paz, Baja California Sur, Mexico
}

Fish commonly known as dolphinfish are members of the family Coryphaenidae, which represents only one genus, Coryphaena, but 2 species, the common dolphinfish (Coryphaena hippurus) and the pompano dolphinfish (C. equiselis) (Gibbs and Collette, 1959).

Dolphinfish, or both species of dolphinfish (hereafter "dolphinfish"), inhabit the tropical and subtropical waters of the world and can be found from $40^{\circ} \mathrm{N}$ to $40^{\circ} \mathrm{S}$ (Palko et al., 1982); they are fast-swimming, fast-growing voracious predators, capable of making considerable migrations (Alejo-Plata et al., 2011) and of passing through different fishery management zones within short periods of time (Farrell, 2009). Their distribution is limited by the $20^{\circ} \mathrm{C}$ isotherm (Palko et al., 1982), and seasonal and interannual changes in sea-surface temperature (SST) influence their local catch rate and abundance (Kraul, 1999; Norton, 1999; Zúñiga-Flores et al., 2008); additionally, their distribution seems to be influenced by prey availability and metabolic needs for sustaining their rapid growth (Schwenke, 2004). These fish are opportunistic preda- tors and feed on a wide spectrum of prey, which includes several species of bony fish, cephalopods, and crustaceans (Aguilar-Palomino et al., 1998; Massutí et al., 1998; Oxenford, 1999; Sakamoto and Kojima; 1999; TrippValdez et al., 2010).

Despite dolphinfish having been reserved for the recreational fishery within $92.6 \mathrm{~km}(50 \mathrm{nmi})$ from the coastline since 1986 (Sosa-Nishizaki, 1998), they are the primary species caught by the artisanal shark fleet in some states of central and south Mexico, where dolphinfish alone can contribute to more than $50 \%$ of the total catch (Madrid and Beltrán, 2001; Damián-Guillén et al., 2010; Miranda-Carrillo et al., 2010). Dolphinfish are also caught incidentally by the tuna purse-seine (Arenas et al., 1999) and longline fleets (Santana-Hernández, 2001), in both coastal and offshore waters off Mexico.

Because of its circumtropical and subtropical distribution and its biological characteristics (fast growth, early maturity, and high fecundity), high catch rates of dolphinfish are reported all over the world, where they are targeted by commercial and recreational fisheries (Martínez-Rincón 
et al., 2009; Farrell et al., 2014). In the Mediterranean Sea, dolphinfish are caught by using a special type of net (called llampuguera) around fish-aggregating devices (Massutí and Morales-Nin, 1997), and in the western Atlantic Ocean, they are caught commercially by using pelagic longlines, and recreationally by rod and reel (Farrell et al., 2014). In South America, it is fished industrially in the Pacific Ocean waters by using surface nets at night near Colombia and Venezuela (Lasso and Zapata, 1999) and by the longline fleets of Ecuador and Costa Rica (Patterson and Martinez, 1991; Campos et al., 1993). In the Pacific Ocean, it is targeted mainly by the Japanese longline fleet (Kojima, 1961).

There are few published works on catch rates and abundance of dolphinfish in relation to environmental parameters. Norton (1999) found, for example, that dolphinfish habitat expanded poleward in the eastern tropical Pacific Ocean, owing to increase in downwelling forced by a long-distance wave transmission along the coast and a decrease in upwelling off the coast of northwestern Mexico, which causes an increase in SST. Zúñiga-Flores et al. (2008) studied seasonal and interannual variation in dolphinfish catch rates in the Cabo San Lucas, Mexico sport fishery. They found a high correlation ( 0.78, with 1-month delay) between monthly mean SST and their catch rate time series. Zúñiga-Flores et al. (2008) reported that dolphinfish catch rates increase toward the second half of the year, when values of SST range between $26^{\circ} \mathrm{C}$ and $29^{\circ} \mathrm{C}$.

Martínez-Rincón et al. (2009) found that most ( $79 \%$ ) dolphinfish caught incidentally by the purseseine tuna fleet in the eastern tropical Pacific Ocean were caught when SST values ranged between $25^{\circ} \mathrm{C}$ and $28^{\circ} \mathrm{C}$, and that no seasonal or interannual spatial pattern was observed. In contrast, Farrell et al. (2014) suggest that chlorophyll- $a$ (chl- $a$ ) concentration and SST are the 2 environmental variables that explain the variations in dolphinfish catch from both the commercial longline and the recreational fisheries in the northwestern Atlantic Ocean. Higher catches occurred in waters with SST between $22^{\circ} \mathrm{C}$ and $27^{\circ} \mathrm{C}$ and chl- $a$ concentrations $<0.2 \mathrm{mg} / \mathrm{m}^{3}$. Farrell et al. (2014) concluded that dolphinfish are highly sensitive to changes in the biophysical environment because a large number of variables was retained in the statistical model fitted to catch data. Apart from SST and chl- $a$ concentration, another variable that could influence dolphinfish abundance is sea-surface height ( $\mathrm{SSH}$ ), which can be used as an indicator of some mesoscale oceanographic features, such as eddies; moreover, some SSH features have elucidated the preference of certain species for particular water masses, such as cyclonic eddies or currents (Zainuddin et al., 2006; Theo and Block, 2010).

Our main objective was to assess environmental and spatial preferences of dolphinfish in the Pacific Ocean off the coast of Mexico by using 1) estimated incidental catch per unit of effort (ICPUE) data from the purseseine tuna fleet and 2) SST, chl- $a$ concentration, and $\mathrm{SSH}$ from remote sensing databases.

\section{Materials and methods}

\section{Fishery database}

We analyzed a 10-year database of estimated dolphinfish caught incidentally, reported by scientific observers of the Inter-American Tropical Tuna Commission on board class 6 (>425 $\mathrm{m}^{3}$ storage capacity; IATTC $\left.{ }^{1}\right)$ tuna purse-seine ships that operated from 2004 to 2013 in the Pacific Ocean off the coast of Mexico from $10^{\circ}$ to $33^{\circ} \mathrm{N}$ and from $90^{\circ}$ to $125^{\circ} \mathrm{W}$. The database included the estimated number of dolphinfish caught monthly in $1^{\circ} \times 1^{\circ}$ latitude-longitude survey quadrants, the number of purse-seine sets that resulted in that estimated number of fish for each quadrant, the number of fish caught per size class of fish (small: $<30 \mathrm{~cm}$ in total length (TL), medium: $30-60 \mathrm{~cm} \mathrm{TL}$, and large: $>60 \mathrm{~cm}$ TL), the coordinates of latitude and longitude at the center of the quadrants, for each month and year. The following equation was used to calculate ICPUE:

$$
I C P U E_{\mathrm{i}}=\frac{D C_{\mathrm{i}}}{N S_{\mathrm{i}}},
$$

where $D C_{\mathrm{i}}=$ estimated catch (total number of dolphinfish); and

$N S_{\mathrm{i}}=$ the number of positive purse-seine sets (with at least one dolphinfish) that resulted in the estimated catch, all for $i$ th quadrant.

\section{Environmental database}

Monthly means for 3 environmental variables over the same 10-year period were used in the analysis: SST, chl- $a$ concentration, and SSH. Both SST and concentration of chl- $a$ were obtained from BloomWatch360, a product of the NOAA CoastWatch West Coast Regional Node (available from website). With this product, each database has a unique 7-letter code. For the SST database, the code is TBssta, has a $0.1^{\circ} \times 0.1^{\circ}$ spatial resolution, and represents a multimission (sent from different sensors) database. The data for chl- $a$ concentration (with a database code of TMHchla) have a $0.05^{\circ} \times 0.05^{\circ}$ resolution, and include data up to September 2013. Data for chl-a concentration for the last 3 months of 2013 were obtained from NOAA's ERDAPP data server (available from website), have a $0.025^{\circ} \times 0.025^{\circ}$ resolution (code erdMBChlamday). Both chl- $a$ concentration data sets come from the Aqua-MODIS satellite. SSH data were obtained from the AVISO website (available from Copernicus at website), with a temporal resolution of $1 \mathrm{~d}$, and a spatial resolution of $0.125^{\circ}$. Monthly averages were then calculated from January 2004 to De-

\footnotetext{
${ }^{1}$ IATTC (Inter-American Tropical Tuna Commission). 2009. Agreement on the International Dolphin Conservation Program. $21^{\text {st }}$ meeting of the parties. Vessel capacity class definitions related to the requirement for carrying an onboard observer. Doc. MOP-21-07, 2 p. IATTC, La Jolla, CA. [Available from website.]
} 
cember 2013. All environmental data were downscaled to $1^{\circ} \times 1^{\circ}$ in order to match the spatial resolution of the fishery database.

\section{Analysis of incidental catch}

Kolmogorov-Smirnov D test and Bartlett's B test were conducted to assess normality and homoscedasticity of the data. Depending on the results, parametric or nonparametric (Kruskal-Wallis $\mathrm{H}$ test) analyses of variance were conducted to evaluate significant seasonal and interannual differences in dolphinfish ICPUE.

Quadrants with catches higher than the lower limit of the upper quartile of ICPUE were considered high catch quadrants (Andrade and Garcia, 1999). Results from these analyses were used to evaluate possible dolphinfish migration patterns.

\section{Relation of dolphinfish incidental catch to environmental and spatial variables}

To assess the relationship of ICPUE to environmental variables, and because of their apparent nonlinear relationship, a $3^{\text {rd }}$ degree polynomial linear model was fitted for each one of the variables in relation to the log-transformed ICPUE. We fitted a model for each different size class, in order to highlight differences in environmental preferences at different dolphinfish life stages. Standard validation techniques (residuals vs. fitted values, histogram of residuals) were used to assess the relevance of the fitted models to the data (Zuur et al., 2009, p. 23). F-tests were then conducted to evaluate the significance of model fit.

With the purpose of evaluating possible segregation due to size, we created histogram-like figures for the estimated number of fish caught per size class of fish and each spatial and environmental variable at the $1^{\circ} \times 1^{\circ}$ resolution. Spatial distribution maps were created with $\mathrm{R}$, vers. 3.0.1 ( $\mathrm{R}$ Core Team, 2013), and its maptools package, vers. $0.8-34$.

The monthly latitude of the $25^{\circ} \mathrm{C}$ isotherm at $120^{\circ} \mathrm{W}$ was extracted from the monthly mean SST data from the satellite imagery by using the contourLines and convCP functions of the R PBSmapping package, vers. 2.68.68. Possible relation between mean latitude of high catch quadrants and mean latitude of the isotherm was explored by using the Pearson correlation coefficient $(r)$.

All calculations were performed with $\mathrm{R}$ and with a significance of 0.05 for all statistical tests.

\section{Results}

\section{Spatiotemporal variation of incidental catch}

A total of 627 positive sets were reported in the 10-year fishery database, which resulted in a total of 55,406 fish caught, and a per-quadrant maximum, minimum, mean, and standard deviation (SD) of 3527, 1, 88.36, and 269.76 fish, respectively. Maximum and minimum
ICPUE values were $3527 \mathrm{fish} / \mathrm{set}$, with a mean of 55.32 fish/set (SD 189.47). The monthly maximum and mean number of positive sets per quadrant was 46 sets and 1.81 sets (SD 3.09).

Data of ICPUE was nonnormally distributed $\left(D_{1}=0.38, P<0.05\right)$ and nonhomoscedastic for monthly $\left(B_{(11,627)}=817.41, P<0.05\right)$ and year-to-year variation $\left(B_{(9}\right.$, $\left.{ }_{627)}=706.81, P<0.05\right)$. With the exception of December, all months had at least one set with 1 fish/set. The highest value of $3527 \mathrm{fish} / \mathrm{set}$ was found during July 2004 . Significant differences were found in monthly ICPUE $\left(H_{(11,627)}=58.85, P<0.05\right)$ : in general, maximum values occurred during June and October, and minimum values occurred during January and November (Fig. 1A).

Yearly, maximum values of ICPUE were found during 2004, and minimum values were reported for 2008 (Fig. 1B). Year-to-year variation was also statistically significant $\left(H_{(9,627)}=26.72, P<0.05\right)$.

Two areas with high dolphinfish concentration $(>300$ fish/set) were found, one in the open ocean around, 10$20^{\circ} \mathrm{N}$ and $115-125^{\circ} \mathrm{W}$, and a second one near the Baja California Peninsula (BCP), around $20-27^{\circ} \mathrm{N}$ and $113-$ $116^{\circ} \mathrm{W}$. Catches around 100-300 fish/set were found in the northern coastal part of the study area $\left(\sim 33^{\circ} \mathrm{N}\right.$, $117^{\circ} \mathrm{W}$ ) and in the entrance of the Gulf of California, around $23^{\circ} \mathrm{N}$ and $107^{\circ} \mathrm{W}$. In the southern part of the study area, scattered quadrants with high estimated ICPUE were also present, especially west of $110^{\circ} \mathrm{W}$ (Fig. 2).

\section{Analysis of size classes}

A total of 5306 dolphinfish (9.50\% of total fish) of the small-size class were caught; $21,387(38.60 \%)$ belonged to the medium-size class, and $28,713(51.82 \%)$ belonged to the large-size class. Number of fish caught by size class was nonnormal $\left(D_{1}=0.41, P<0.05\right)$ and nonhomoscedastic $\left(B_{(2,1881)}=347.83, P<0.05\right)$. Significant differences were found between fish caught for different size classes $\left(H_{(2,1881)}=449.25, P<0.05\right)$. An average of 8.50 fish (SD 74.30) in the small-size class (min. 0, max. 1706) were caught per quadrant per month. Mean for the medium- and large-size classes were 34.10 fish (SD 151.03; min. 0, max. 2185) and 45.80 fish (SD 153.44; min.0, max. 1689) per quadrant per month, respectively.

No apparent well-defined spatial pattern due to size class was observed. Dolphinfish of all size classes were caught both on coastal and offshore waters throughout the study area (results not shown).

For the small-size class, most fish were caught during July (45\% of total fish for that size class, 2428 fish), and 0 fish were caught during December. July was also the month when most incidental catch of fish in the mid-size class occurred $(30.50 \%$ of total fish [6521 fish for the size class]). Only $0.03 \%$ ( 8 fish) of total fish of the medium-size class were caught during December. For the large-size class, most fish were caught during October $(32.22 \%$ of total fish for the size class, 9522 fish), and a monthly minimum of $0.08 \%$ of total fish 


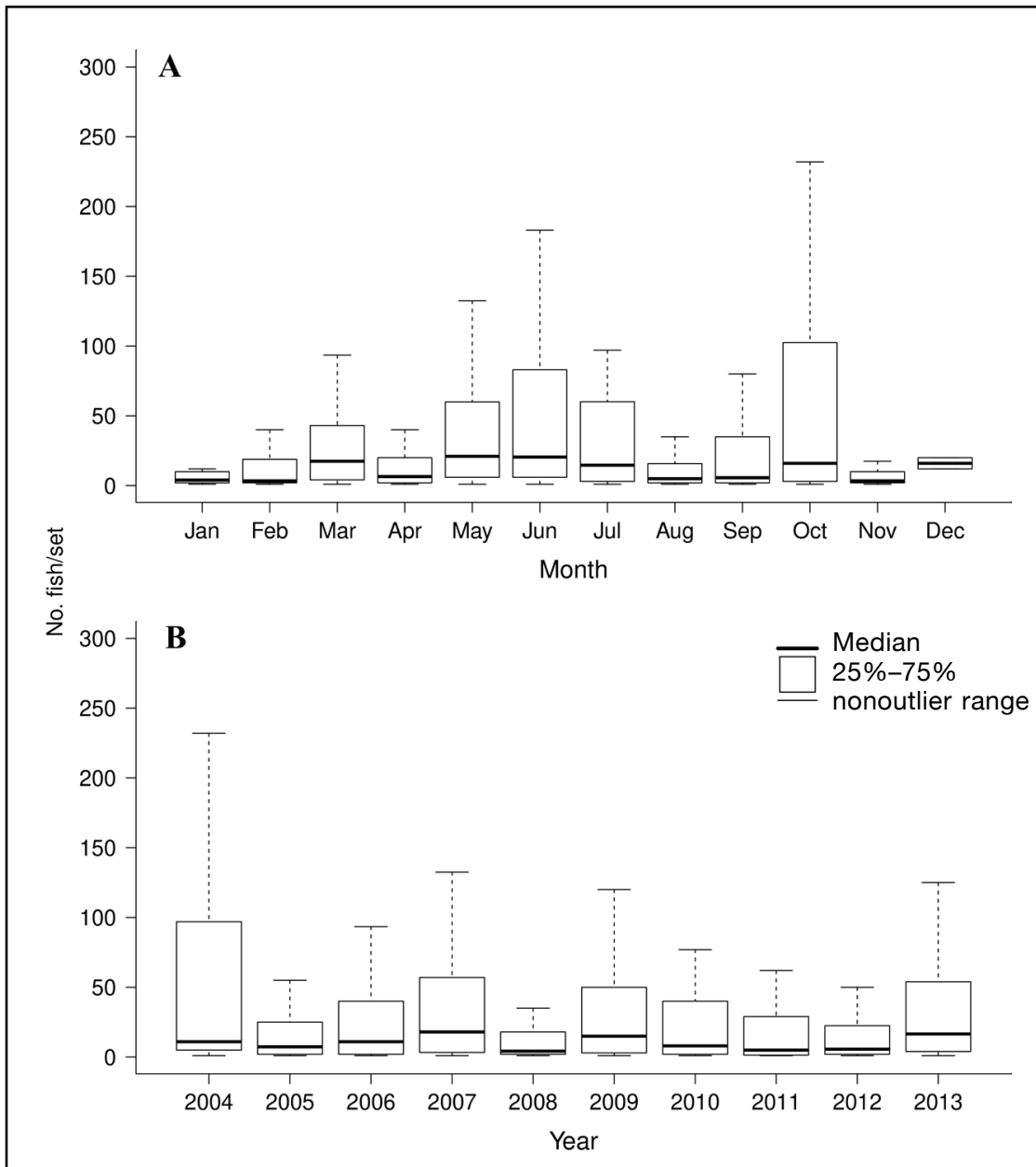

Figure 1

Variation between $(\mathbf{A})$ months and (B) years in estimated incidental catch per unit of effort of common dolphinfish (Coryphaena hippurus) and pompano dolphinfish (C. equiselis) in the eastern Pacific Ocean off Mexico during 20042013. The thick black line is the median, the box displays the $25 \%$ and $75 \%$ quartiles, and the whiskers extend 1.5 times beyond the interquartile range.

(24 fish) were reported during December for this size class (Fig. 3A).

Highest incidental catch occurred during 2004, where $40 \%$ (2121), 28\% (5977), and $22.50 \%$ (6453) of total fish for the 10-year period were caught for the small-, medium-, and large-size classes, respectively. Lowest annual incidental catch occurred during 2008 for the small-size class $(0.50 \%$ of total fish for this size class, 26 fish) and the medium-size class $(2.40 \%$ of total fish for this size class, 507 fish), and during 2011 for the large-size class (2.70\%, 782 fish) (Fig. 3B).

\section{Summary of environmental variables}

A wide range of SST, chl- $\alpha$ concentration, and SSH values was found in the study area, during the 10-year period. Maximum, minimum, and mean values for SST were $33.12^{\circ} \mathrm{C}, 12.54^{\circ} \mathrm{C}$, and $24.54^{\circ} \mathrm{C}$ (SD 4.28). Chl-a concentration ranged from 0.02 to $38.76 \mathrm{mg} / \mathrm{m}^{3}$, with a mean of $0.51 \mathrm{mg} / \mathrm{m}^{3}$ (SD 1.47). Lowest $\mathrm{SSH}$ value for the study period was $-0.30 \mathrm{~m}$, with a maximum of 0.39 $\mathrm{m}$, and a mean of $0.02 \mathrm{~m}$ (SD 0.07).

\section{Environmental and spatial preferences per class size}

Residuals vs. fitted values in scatter plots for fitted polynomial models showed no clear pattern for any of the environmental variables, and the histograms of the residuals were apparently normal (results not shown) in all cases, which suggests good fits (Zuur et al., 2009). Large and small dolphinfish incidental catch per unit of effort (ICPUE) peaked at $\sim 24^{\circ} \mathrm{C}$, whereas medium-size fish ICPUE peaked at $\sim 26^{\circ} \mathrm{C}$ (Fig. $4 \mathrm{~A}$ ). Most fish were caught in waters with low $(<0.15 \mathrm{mg}$ / $\mathrm{m}^{3}$ ) chl- $a$ concentrations, but 2 interesting peaks in catch occurred for small- and medium-size fish in wa- 


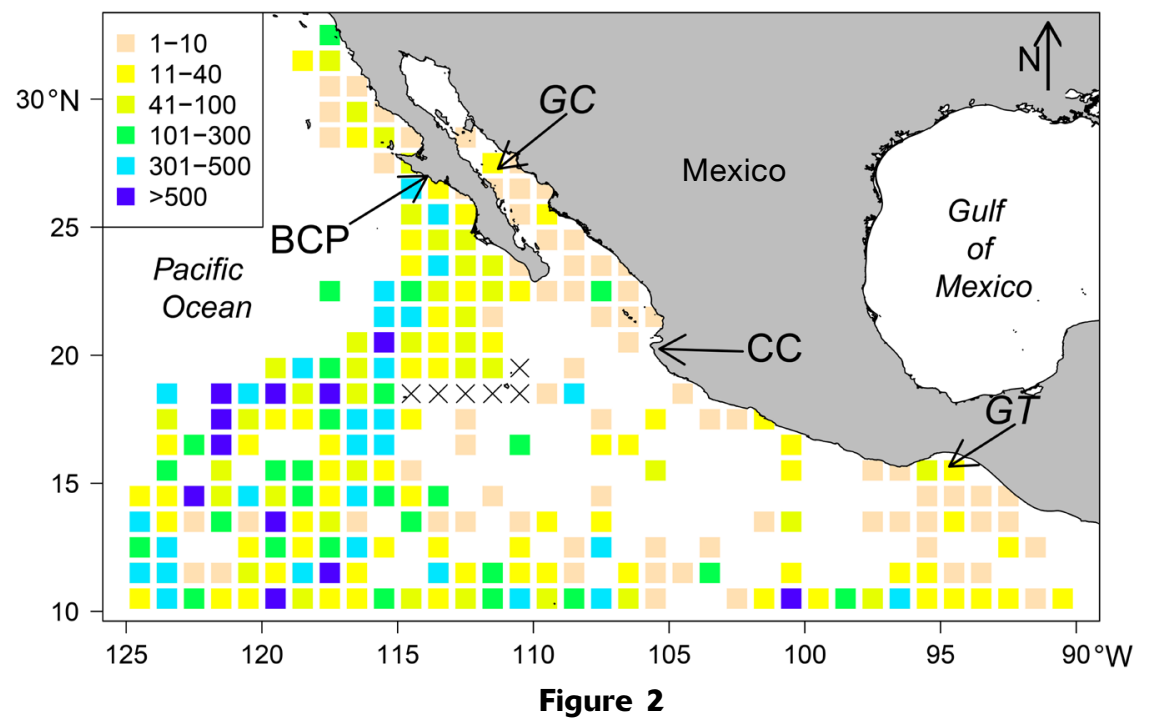

Map of the spatial distribution of estimated incidental catch per unit of effort (ICPUE) of common dolphinfish (Coryphaena hippurus) and pompano dolphinfish (C. equiselis) for the period 2004-2013 in the eastern Pacific Ocean off Mexico. The scale indicates ICPUE measured in number of fish caught per set. An $\times$ indicates areas where fishing is prohibited. Arrows indicate the Gulf of California (GC), Baja California Peninsula (BCP), Cabo Corrientes (CC), and Gulf of Tehuantepec (GT). between logarithm of ICPUE and SST was significant only for medium- and large-size dolphinfish $\left(F_{(4,}\right.$ $306)=7.52, P<0.05$ and $F_{(4,423)}=16.02$, $P<0.05)$, whereas chl- $a$ concentration and ICPUE were significant of all 3 size classes $\left(F_{(4,92)}=13.71\right.$, $P<0.05, F_{(4,304)}=22.78, P<0.05$ and $F_{(4,423)}=46.68, P<0.05$ for small, medium-size, and large fish). Relationship of catch and SSH was not as clear $(F=\sim 1 ; P>0.22$ for all 3 size classes).

No apparent spatial segregation due to size was observed, but some spatial patterns arose when an analysis per latitudinal bands was applied. Of the total fish in the small-size class, $33.39 \%$ (1719 fish) were caught between $20^{\circ} \mathrm{N}$ and $22^{\circ} \mathrm{N}$. On the other hand, for the medium-size class, $24.30 \%$ of total fish (4893 fish) were caught between $10^{\circ} \mathrm{N}$ and $12^{\circ} \mathrm{N}$. For the large-size class, there was a prominent mode at the southernmost latitudinal band $\left(10-12^{\circ} \mathrm{N}\right)$, where $27.30 \%$ of total fish (7177 fish) were

caught (Fig. 5A).

A total of 2090 fish (41.50\% of total fish) in the small-size class were caught between $114^{\circ} \mathrm{W}$ and $116^{\circ} \mathrm{W}$. Fish for the medium-size class were distributed west of $113^{\circ} \mathrm{W}$ and the maximum number of fish (4708, $23.50 \%$ of total fish) were caught between $117^{\circ} \mathrm{W}$ and $120^{\circ} \mathrm{W}$. The most important mode for the large-size fish $\left(6242,24 \%\right.$ of total fish) was found between $114^{\circ} \mathrm{W}$ and $117^{\circ} \mathrm{W}$ (Fig. 5B).

The maximum and minimum SST values from quadrants where at least one dolphinfish was caught were $31.10^{\circ}$ and $18.50^{\circ} \mathrm{C}$. Despite this wide range, dolphinfish showed a clear preference for warm waters. Almost $40 \%$ (38.20\%, 1926 fish) of total fish belonging to the small-size class were caught between $25^{\circ} \mathrm{C}$ and $26^{\circ} \mathrm{C}$. The main mode for the incidental catch of fish in the medium- and large-size classes was found between $27^{\circ} \mathrm{C}$ and $28^{\circ} \mathrm{C}$, with $38.60 \%$ (7755) and $36.82 \%$ (9711) of total fish caught for the medium- and largesize class, respectively (Fig. 5C).

Chl- $a$ concentration also showed a wide range (0.05$2.61 \mathrm{mg} / \mathrm{m} 3$ ) for those quadrants with positive sets. However, $82.90 \%$ of total fish, in all 3 size classes was caught in waters with concentrations of chl- $a$ between 0.05 and $0.25 \mathrm{mg} / \mathrm{m}^{3}(3877,75 \%$ of total fish, for the small-size class, $16,092,80 \%$ of total fish for the medium-size class, and 22,764, $86 \%$ of total fish for the large-size class; Fig. 5D).

Dolphinfish were caught incidentally in $\mathrm{SSH}$ values ranging from -0.13 to $0.32 \mathrm{~m}$. Of total fish (2047) of the small-size class, $40 \%$ were caught in waters with SSHs from 0.05 to $0.1 \mathrm{~m}$. For the medium-size class, ters with high $\left(>1 \mathrm{mg} / \mathrm{m}^{3}\right)$ chl- $a$ concentrations (Fig. 4B). A similar result was found in respect to SSH preferences for the 3 size classes, with higher catch in waters with positive SSH values (Fig 4C). Relationship 

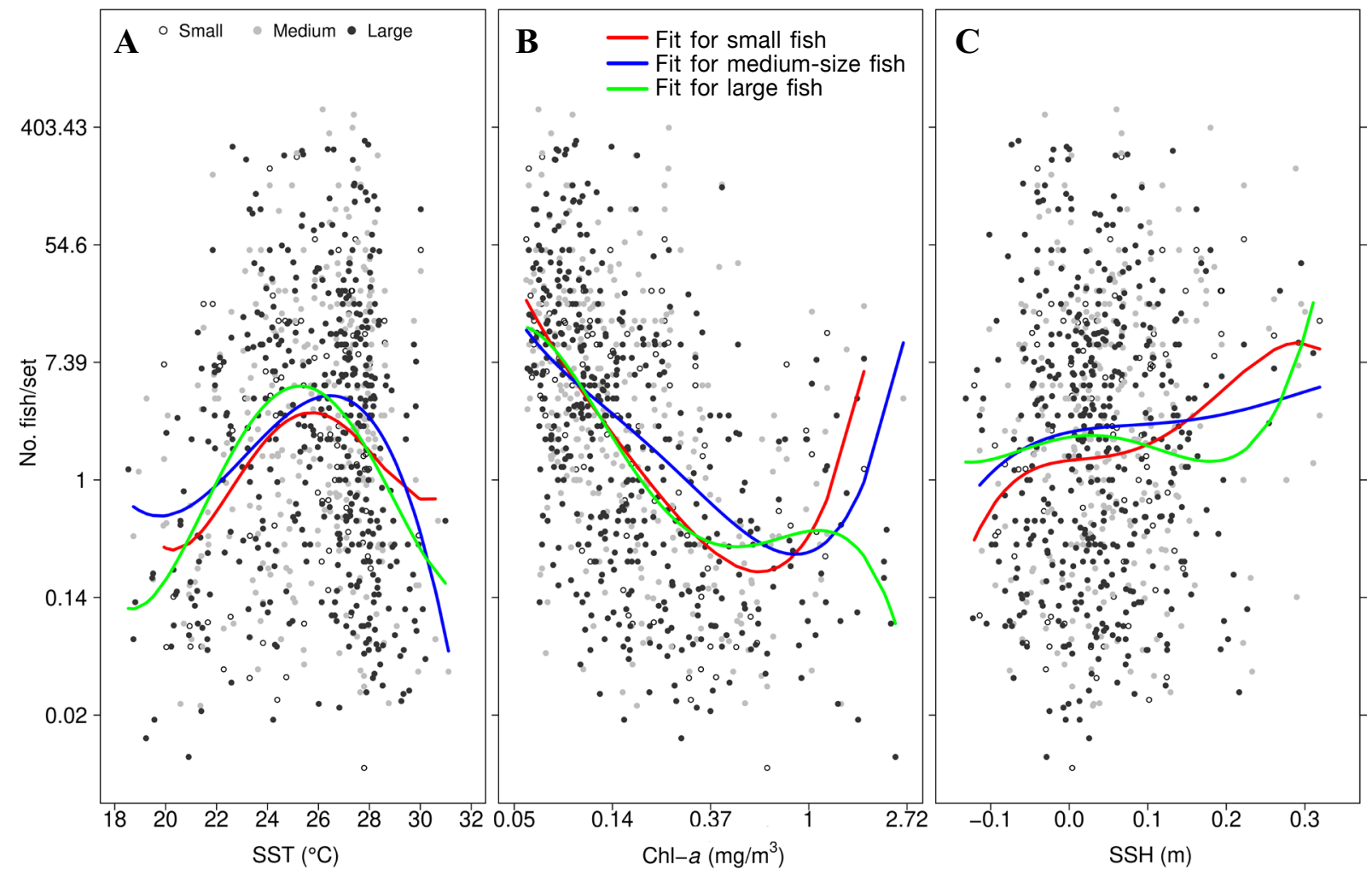

Figure 4

Scatter plots of the relationship between incidental catch per unit of effort (in logarithmic scale) for each size class of dolphinfish (Coryphaena spp.) and (A) sea-surface temperature (SST), (B) chlorophyll- $a$ concentration (chl- $a$ ), and (C) sea-surface height (SSH) in the eastern Pacific Ocean off Mexico during 2004-2013. Points indicate observed values, and the colored lines were generated by fitting the polynomial linear models to the data.

7674 fish (38\% of total fish in this class) were caught in waters with $\mathrm{SSH}$ from 0.05 to $0.1 \mathrm{~m}$, and 5149 fish ( $25 \%$ of total fish in this class) for this size class were caught in $\mathrm{SSH}$ values from -0.05 to $0 \mathrm{~m}$. Fish in the large-size class showed SSH preferences similar to those in the medium-size class, with 27\% (7229 fish for this class) and $23 \%$ (6059 fish) of total fish caught in $\mathrm{SSH}$ ranges from -0.05 to $0 \mathrm{~m}$ and from 0.05 to $0.1 \mathrm{~m}$, respectively (Fig. 5E).

Figure 6 shows the spatial distribution of total estimated ICPUE and (A) mean SST, (B) chl- $a$ concentration, and (C) SSH values for the whole study area.

In general, most dolphinfish catches occurred south of the $21^{\circ} \mathrm{C}$ isotherm, especially around the $25^{\circ} \mathrm{C}$ isotherm, and few catches occurred in waters with SSTs over $28^{\circ} \mathrm{C}$. The 10 -year average SST values higher than $21^{\circ} \mathrm{C}$ and lower than $28^{\circ} \mathrm{C}$ occurred both in the oceanic zone and near the coast of the BCP, especially in the central portion of the study area, and in the Gulf of California. Values higher than $28^{\circ} \mathrm{C}$ occurred near the coast, south of $18^{\circ} \mathrm{N}$ and east of $110^{\circ} \mathrm{W}$.

The vast majority of dolphinfish ICPUE occurred, for the 10 -year average, west of the $0.20 \mathrm{mg} / \mathrm{m}^{3}$ isoline. This area with values of chl- $a$ concentration lower than $0.20 \mathrm{mg} / \mathrm{m}^{3}$ represented most of the oceanic zone, with the exception of an area east of $\sim 104^{\circ} \mathrm{W}$. High (>1 mg/ $\mathrm{m}^{3}$ ) values were found in coastal zones, especially in the upper Gulf of California, the west coast of the BCP, the Cabo Corrientes area $\left(\sim 21^{\circ} \mathrm{N}, 105^{\circ} \mathrm{W}\right)$, and the Gulf of Tehuantepec, in the southern portion of the study area.

The 10-year average for $\mathrm{SSH}$ resulted in positive values for the study area. Most dolphinfish were caught in or near the $0.02 \mathrm{~m} \mathrm{SSH}$ isoline, which was located mainly in an oceanic area around $11-18^{\circ} \mathrm{N}$ and $125-110^{\circ} \mathrm{W}$. In the west coast of the BCP, high ICPUE occurred where SSH values were greater than $0.03 \mathrm{~m}$.

\section{Analysis of high-catch quadrants and their relationship with the $25^{\circ} \mathrm{C}$ isotherm}

The lower limit of the upper quartile of the ICPUE vector was $42.62 \mathrm{fish} / \mathrm{set}$; hence, all the quadrants with catches higher than this value were considered high-catch quadrants. Mean monthly latitude for these quadrants increased from January through August and then decreased from August to November, and no high catch quadrants were observed during December. The opposite was observed in the monthly mean longitude for these quadrants: a decrease from January to August and an increase from August to November (results not shown). When visualized in latitude and longitude 


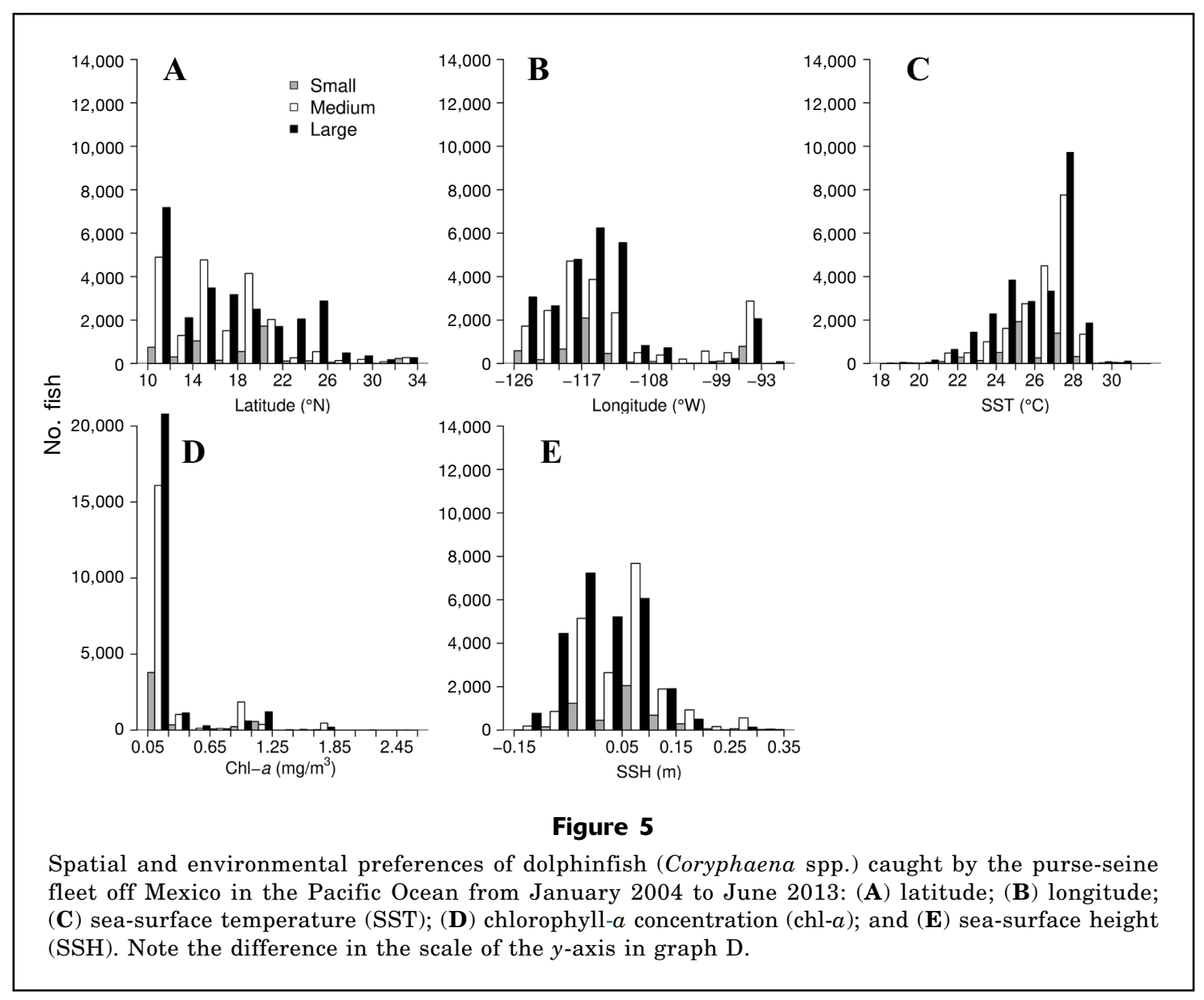

coordinates on a map (i.e., "centroids"), areas with high dolphinfish ICPUE moved north westward during the months of April-May, and from south eastward during September-October (Fig. 7).

Mean monthly latitudes of high catch quadrants and position of $25^{\circ} \mathrm{C}$ isotherm at $120^{\circ} \mathrm{W}$ showed a similar pattern, although a 1-month lag was visible for the peaks of the 2 curves: maximum latitude for the isotherm occurs 1 month later than the maximum mean latitude of the quadrants (Suppl. Fig. 1). A high $r$ of 0.84 was found, which was significantly different from $0(P<0.05)$.

\section{Discussion}

Two areas of high dolphinfish ICPUE were present in the study area, one on the west coast of the BCP, where practically all ICPUE occurs during August $\left(20-27^{\circ} \mathrm{N}\right.$ and $\left.113-116^{\circ} \mathrm{W}\right)$, and a second one in an oceanic zone (around $10-20^{\circ} \mathrm{N}$ and $115-125^{\circ} \mathrm{W}$ ), where higher ICPUE occurs during May-June. July seems to be a month of transition between areas of high catch because a large area of relatively high abundance is observed, which covers the northern portion of the oceanic area and the southern portion of the BCP high catch area (Suppl. Fig. 2). Two of the potential factors that determine dolphinfish presence are the occurrence of floating objects and variations in SST; unfortunately, the relationship of ICPUE with floating objects could not be explored because of limited data. In terms of environmental factors, such as SST, it is well known that the upwelling of subsurface cool waters favors the development of the oceanic food web by bringing nutrients into the photic upper ocean layer (Reilly, 1990). Along the western coast of the BCP, wind blows parallel to the coast and causes intense upwelling (Zaytzev et al., 2003) during March-June because of the Ekman transport; these upwelling events can last up to $10 \mathrm{~d}$ (Walsh et al., 1977; Cervantes-Duarte et al., 1993) and are capable of concentrating plankton feeders such as the red pelagic crab (Pleuroncodes planipes), one of the main sources of food for dolphinfish and other large pelagic fish in this area (Aguilar-Palomino et al., 1998; Tripp-Valdez, 2005; Martínez-Rincón et al., 2009). Ortega-García and Lluch-Cota (1996) found a 3-month lag between spatial chlorophyll fronts (with peak chl-a concentration) and peaks in high abundance of yellowfin tuna (Thunnus albacares). Because yellowfin tuna and dolphinfish share habitat to some extent, the same $\sim 3$ month lag could also help to explain high dolphinfish abundance in the BCP during August-September, 

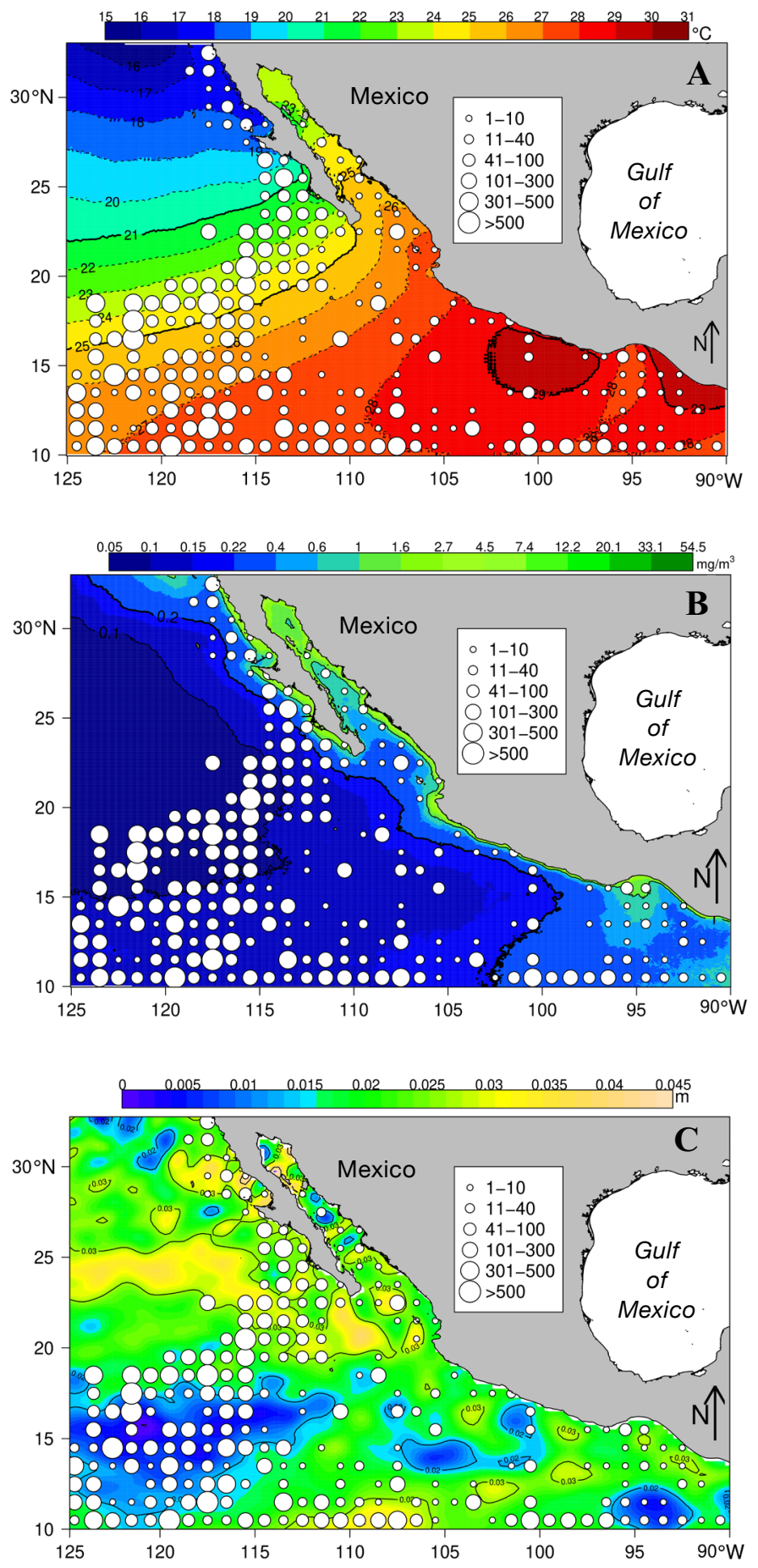

Figure 6

Maps of the spatial distribution of total estimated incidental catch per unit of effort in the eastern Pacific Ocean off Mexico, the number of fish per set indicated by the size of the white circles, and mean values of (A) sea-surface temperature (measured in degrees Celsius), (B) chlorophyll- $a$ concentration (measured in milligrams per cubic meter) and (C) sea-surface height (measured in meters) for the 10-year period 2004-2013. The scale at the top of each panel indicates levels for 1 of the 3 environmental parameters.
2-4 months after the conclusion of the upwelling season along the west coast of BCP, when the food web is fully "mature" for large pelagic pray, and SST is optimal for dolphinfish.

In the ocean zone where a high ICPUE is reported, there is also a current pattern that seasonally optimizes the SST for dolphinfish. The California Current System is the eastern part of the North Pacific Subtropical Gyre, which reaches the BCP (Badan, 1997). Part of the California Current turns westward, at around $15^{\circ} \mathrm{N}, 112^{\circ} \mathrm{W}$, as evident by the curvature of the isotherms, and becomes the North Equatorial Current (Karl, 1999; Fiedler and Talley, 2006). In this area thermal fronts occur when the cold California Current meets the Eastern Pacific Warm Pool, an area in the central Pacific Ocean off the coast of Mexico, characterized by temperatures $>27.5^{\circ} \mathrm{C}$ all year long (Fiedler and Talley, 2006; Kessler, 2006), as a result of large net heat flux and poor wind mixing (Wang and Enfield, 2001, cited by Fiedler and Talley, 2006). Additionally, the North Pacific Subtropical Gyre is anticyclonic and characterized by low productivity and a high pressure center (Lalli and Parsons, 1997), both of which suggest that low production areas occur on both sides of the branch of the California Current that joins the Equatorial Current System; a branch that spatially agrees with the oceanic area of high ICPUE.

The direction and intensity of the California Current has a pattern similar to that of oceanic wind (Pantoja et al., 2012), and both are strongest during winter (Martínez-Rincón et al., 2009; Marín-Enríquez, 2012). Assuming that the 3-month lag hypothesis of Ortega-García and Lluch-Cota (1996) also applies to this oceanic area, because dolphinfish arrive during May-June, 3-4 months after the winter season, the California Current enters a dormant state, and tropical water masses, with high temperature and low salinity (Torres-Orozco, 1993) move northwards, bringing the preferred SST values to the high ICPUE zone for dolphinfish.

Survey quadrants with high ICPUE were scattered throughout the southernmost part of the study area, especially from February through April (Suppl. Fig. $1)$. This zone $\left(0^{\circ}-10^{\circ} \mathrm{N}\right)$ is under the influence of the Equatorial Current System and is a highly productive zone because of the upwelling caused by the trade winds (Martínez-Rincón et al., 2009). In the zone of the equatorial cold-upwelled water tongue, trade winds, and upwelling are more intense during winter months (Kessler, 2006, fig. 9). Mann and Lazier (1996) suggested that high trophic level predators, such as sharks, tunas, and other fish use this area as feeding grounds because of the high prey abundance resulting from the nutrient-rich upwelling process. Bocanegra Castillo (2007) suggested that billfish, sharks, and dolphinfish feed on a wide variety of prey in this area, such as crustaceans, small fish, and squid. The relatively high ICPUE in this zone could then be explained by the time lag that it takes the trophic web to "climb" up to the trophic levels of the prey that dolphinfish feed 


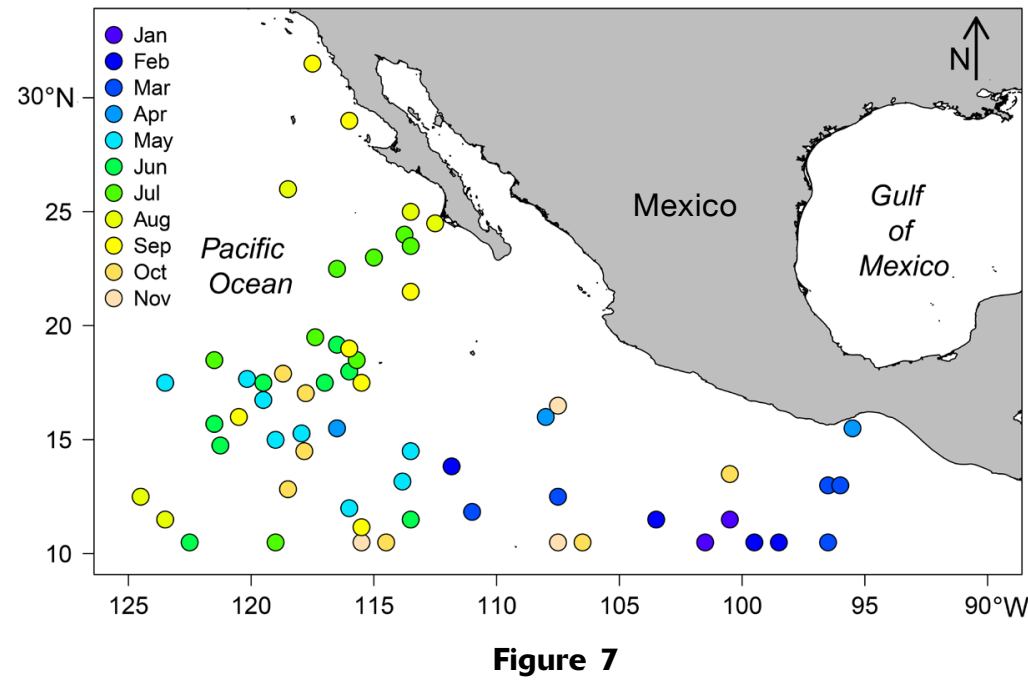

Mean geographic locations (centroids) of survey quadrants $\left(1^{\circ} \times 1^{\circ}\right)$ with high ( $>42.62$ fish/set) monthly mean incidental catch per unit of effort for dolphinfish (Coryphaena spp.) in the Pacific Ocean off Mexico during 2004-2013

on-a climb that occurs $\sim 4-5$ months after the peak in trade winds and upwelling activity.

Year-to-year variation in ICPUE was also quite variable. During our study period, higher ICPUE occurred during 2004, one of the years with higher SST values (results not shown); according to NOAA's Oceanic Niño Index (ONI, available from website), there was a moderate to strong warm episode during 2004 . Lower ICPUE was recorded during 2008, a year with low SST and negative (i.e., "cold period") ONI values. Another period of low ICPUE occurred during 20112012, a period dominated by negative ONI values; however, during 2013 a high ICPUE peak agreed with a year of negative ONI values, and therefore yearto-year variability of ICPUE has a week correlation with ONI and indicates that biotic and abiotic factors other than SST may influence relative abundance of dolphinfish.

To the best of our knowledge, this study provides the first approach to assess ontogenetic variations in dolphinfish habitat preferences. For both small and large fish, ICPUE showed a peak at $\sim 25^{\circ} \mathrm{C}$, nearly $2^{\circ} \mathrm{C}$ lower than the peak for medium-size fish $\left(\sim 27^{\circ} \mathrm{C}\right)$. Kraul (1999) suggested that dolphinfish growth rate is very sensitive to temperature, which would imply larger discrepancies in thermal preferences for small and large fish and is opposite to what we observed. One explanation might be that medium-size fish have different metabolic needs than small and large fish, perhaps because they are reaching size at first maturity (Alejo-Plata et al., 2011). However, this hypothesis needs to be validated, perhaps with a controlled experimental design, such as those designed for aquaculture purposes.

Fitted models show that there was 2 interesting peaks of ICPUE at relatively high $\left(>1 \mathrm{mg} / \mathrm{m}^{3}\right)$ chl- $a$ concentrations for small and medium-size fish. Kitchens and Rooker (2014) found that dolphinfish larvae density increases with higher concentrations of chl- $a-a$ finding that suggests that fast-growing larvae survive in areas of enhanced food availability, such as cold-core eddies and fronts. The fact that some fish $<60 \mathrm{~cm}$ TL are caught in these "high" chl- $a$ concentrations might be explained by the energetic needs that dolphinfish require in their early, fast-growth life stage (Zúñiga-Flores, 2009). Additionally, Olson and Galván-Magaña (2002) found that dolphinfish body and prey size are positively correlated, and therefore smaller dolphinfish might explore areas of high productivity, where smaller prey are expected to be more abundant. Olson and Galván-Magaña (2002) also found that dolphinfish food consumption rates are different for males and females in early life stages, and therefore sex could also be playing an important role in the differences presented in our study.

Overall, dolphinfish shows a clear preference for SSTs between $23^{\circ} \mathrm{C}$ and $28^{\circ} \mathrm{C}$, chl- $\alpha$ concentration $<0.2 \mathrm{mg} / \mathrm{m}^{3}$, and $\mathrm{SSH}$ values from -0.05 to $0.05 \mathrm{~m}$. Dolphinfish thermal preferences have been reported by other authors, such as Martínez-Rincón et al. (2009), who suggest that temperatures below $20^{\circ} \mathrm{C}$ may limit the metabolism and growth of this species. Norton (1999) reports that dolphinfish move to warmer waters when a decrease in SST occurs, and that fish habitat expands northwards during events of extreme increase in SST. In addition to the 2 areas with high catch that were mentioned earlier, low ICPUE occurred in an area around $11-18^{\circ} \mathrm{N}$ and $97-110^{\circ} \mathrm{W}$, in the zone of the Eastern Pacific Warm Pool. As stated before, some authors suggest that dolphinfish abundance increases with high temperatures (Zúñiga-Flores et al., 2008); however, our findings suggest that optimal temperatures for dolphinfish are between $25^{\circ} \mathrm{C}$ and $28^{\circ} \mathrm{C}$ (with an important decrease in ICPUE at temperatures $>28^{\circ} \mathrm{C}$ ), which could explain the low ICPUE area in the Eastern Pacific Warm Pool, an area that is characterized by high $\left(>27.5^{\circ} \mathrm{C}\right) \mathrm{SST}$ values all year long (Fiedler and Talley, 2006).

A wide range of $\mathrm{SSH}$ values were found in the study area, although high ICPUE occurred only over a narrow range of both positive and negative values. Positive SSH values indicate a zone of convergence (anticyclonic activity) in the Northern Hemisphere (Lalli and Parsons, 1997) and indicate that dolphinfish associate with anticyclonic structures-a behavior that has been reported for other large pelagic fish, such as the albacore (Thunnus alalunga) (Zainuddin et al., 2006).

Additionally, in respect to the possible effect of migrations during the seasonality of dolphinfish catch, Kraul (1999) suggested that dolphinfish can spawn several times a year, that some cohorts are "stronger" than others, and that the survivors of those strong 
cohorts could also influence the seasonal analysis of catch. Given the growth curve proposed by ZúñigaFlores (2009), dolphinfish of the small-size class would be less than 3 months old, the medium-size individuals would be between 3 and 6 months old, and the large fish would be more than 6 months old. Substantial differences have been found in size at first maturity for one of the species in our study for Coryphaena hippurus, dolphinfish, in the southern part of our study area (Gulf of Tehuantepec); the dolphinfish matures at $\sim 50$ $\mathrm{cm}$ in fork length (FL) (Alejo-Plata et al., 2011), and in the central part (southern tip of the BCP), at around $80 \mathrm{~cm}$ FL (Zúñiga-Flores et al., 2011). Dolphinfish of the small-size class would then probably be all immature individuals; the medium- and large-size class of fish could be a mixture of mature and immature fish. If we assume that large-size class of fish are mature fish, a large number of potential spawners should have been present during October in the study area. Following the hypothesis of Kraul (1999), we could expect a high abundance of juveniles for the first months of the following year-a pattern that was not fully clear and needs to be investigated; it is worth noting that all these published works refer mainly to only one species, the common dolphinfish, and therefore these inferences are made for that particular species.

\section{Literature cited}

Aguilar-Palomino, B., F. Galván-Magaña, L. A. Abitia-Cárdenas, A. F. Muhlia-Melo, and J. Rodríguez-Romero. 1998. Feeding aspects of the dolphin Cmyphaena hippurus Linnaeus, 1758 in Cabo San Lucas, Baja California Sur, Mexico. Cienc. Mar. 24:253-265.

Alejo-Plata, C., P. Díaz-Jaimes, and I. H. Salgado-Ugarte.

2011. Sex ratios, size at sexual maturity, and spawning seasonality of dolphinfish (Coryphaena hippurus) captured in the Gulf of Tehuantepec, Mexico. Fish. Res. 110:207-216. Article

Andrade, H. A., and C. A. E. Garcia.

1999. Skipjack tuna in relation to sea surface temperature off the southern Brazilian coast. Fish. Oceanogr. 8:245-254. Article

Arenas, P., M. Hall, and M. García.

1999. Association of fauna with floating objects in the eastern Pacific Ocean. In Proceedings of the international workshop on the ecology and fisheries for tunas associated with floating objects. IATTC Spec. Rep. 11; 11-13 February 1992, p. 285-326. Inter-Am. Trop. Tuna Comm., La Jolla, CA.

Badan, A.

1997. La corriente costera de Costa Rica en el Pacífico Mexicano. In Contribuciones a la oceanografía física en México. Monografía 3 (M. F. Lavín, ed.), p. 99112. Unión Geofísica Mexicana, Ensenada, Mexico.

Bocanegra Castillo, N.

2007. Relaciones tróficas de los peces pelágicos asociados a la pesquería del atún en el Océano Pacífico oriental. Ph.D. diss., 178 p. Cent. Interdiscip. Cienc. Mar., Inst. Politéc. Nac., La Paz, Mexico.
Campos, J. A., A. Segura, O. Lizano, and E. Madrigal. 1993. Ecología básica de Coryphaena hippurus (Pisces: Coryphaenidae) y abundancia de otros grandes pelágicos en el Pacifico de Costa Rica. Rev. Biol. Trop. 41:783-790.

Cervantes-Duarte, R., S. Aguíniga-Garcia, and S. HernándezTrujillo.

1993. Upwelling conditions associated to the distribution of zooplankton in San Hipolito, B.C.S. Cienc. Mar. 19:117-135.

Damián-Guillén, M., S. R. Soriano-Velázquez, C. E. RamírezSantiago, and D. E. Acal-Sánchez.

2010. Captura incidental de la flota artesanal tiburonera del puerto de Zihuatanejo, Guerrero. In Proceedings of the symposium: $\mathrm{V}$ foro científico de pesca ribereña; Boca del Río, Mexico, 7-9 September (E. Espino-Barr, M. A. Carrasco-Águila, E. Romero-Hernández, H. Aguirre-Villaseñor, and O. Miranda-Carrillo, eds), p. 45-46. Inst. Nac. Pesca, Mexico City, Mexico.

Farrell, E. R.

2009. The habitat, movements, and management of dolphin, Coryphaena hippurus, in the western North Atlantic, Caribbean, and Gulf of Mexico. M.S. thesis, $55 \mathrm{p}$. Nicholas School Environ., Duke Univ., Durham, NC.

Farrell, E. R., A. M. Boustany, P. N. Halpin, and D. L Hammond.

2014. Dolphinfish (Coryphaena hippurus) distribution in relation to biophysical ocean conditions in the northwest Atlantic. Fish. Res. 151:177-190. Article

Fiedler, P. C., and L. D. Talley.

2006. Hydrography of the eastern tropical Pacific: a review. Prog. Oceanogr. 69:143-180. Article

Gibbs, R. H., Jr., and B. B Collette.

1959. On the identification, distribution, and biology of dolphins, Coryphaena hippurus and C. equiselis of The Gulf and Caribean. Bull. Mar. Sci. 9:117-152.

Karl, D. M.

1999. A sea of change: biogeochemical variability in the North Pacific Subtropical Gyre. Ecosystems 2:181-214. Article

Kessler, W. S.

2006. The circulation of the eastern tropical Pacific: a review. Prog. Oceanogr. 69:181-217. Article

Kitchens, L. L., and J. R. Rooker.

2014. Habitat associations of dolphinfish larvae in the Gulf of Mexico. Fish. Oceanogr. 23:460-471. Article

Kojima, S.

1961. Studies of fishing conditions of dolphin, Coryphaene hippurus, in the western region of the Sea of Japan. III. On food contents of dolphin. Bull. Jpn. Soc. Sci. Fish. 27:625629. Article

Kraul, S.

1999. Seasonal abundance of dolphinfish, Coryphaena hippurus, in Hawaii and the tropical Pacific Ocean. Sci. Mar. 63:261-266.Article

Lalli, C. M., and T. R. Parsons.

1997. Biological oceanograpy: an introduction, $2^{\text {nd }}$ ed., 324 p. Elsevier Butterworth-Heinemann, Oxford, UK.

Lasso, J., and L. Zapata.

1999. Fisheries and biology of Coryphaena hippurus (Pisces: Coryphaenideae) in the Pacific coast of Colombia and Panama. Sci. Mar. 63:387-399. Article 
Madrid, J. V., and R. Beltrán-Pimienta.

2001. Longitud, peso y sexo del dorado Coryphaena hippurus (Perciformes: Coryphaenidae), del litoral de Sinaloa, Nayarit y Baja California Sur, México. Rev. Biol. Trop. 49:931-938.

Mann, K. H., and J. R. N. Lazier.

1996. Dynamics of marine ecosystems: biological-physical interactions in the oceans, $2^{\text {nd }}$ ed., 394 p. Wiley-Blackwell, Inc., Hoboken, NJ.

Marín-Enríquez, E.

2012. Variabilidad de las tasas de captura de Marlin Azul (Makaira nigricans) en la entrada del Golfo de California, y su relación con algunas variables oceanográficas. M.S. thesis, 67 p. Cent. Interdiscip. Cienc. Mar., Inst. Politéc. Nac. La Paz, Mexico.

Martínez-Rincón, R. O., S. Ortega-García, and J. G. Vaca-Rodríguez.

2009. Incidental catch of dolphinfish (Coryphaena spp.) reported by the Mexican tuna purse seiners in the eastern Pacific Ocean. Fish. Res. 96:296-302. Article

Massutí, E., and B. Morales-Nin.

1997. Reproductive biology of dolphin-fish (Coryphaena hippurus L.) off the island of Majorca (Western Mediterranean). Fish. Res. 30:57-65. Article

Massutí, E., S. Deudero, P. Sánchez, and B. Morales-Nin.

1998. Diet and Feeding of dolphin (Coryphaena hippurus) in western Mediterranean waters. Bull. Mar Sci. 63:329-341.

Miranda-Carrillo, O., E. Espino-Barr, E. Cabral-Solís, M. Puente-Gómez, A. García-Boa, and F. J. De La Cruz-Gonzáles. 2010. Aspectos de la pesca ribereña en la Bahía de Barra de Navidad, Jalisco, 2007 a 2009. In Proceedings of the symposium: $\mathrm{V}$ foro científico de pesca ribereña, Boca del Río, Mexico, 7-9 September (E. Espino-Barr, M. A. Carrasco-Águila, E. Romero-Hernández, H. Aguirre-Villaseñor, and O. Miranda-Carrillo, eds.), p. 147148. Inst. Nac. Pesca, Mexico City, Mexico.

Norton, J. G.

1999. Apparent habitat extensions of dolphinfish (Coryphaena hippurus) in response to climate transients in the California Current. Sci. Mar. 63: 239-260. Article

Olson, R. J., and F. Galván-Magaña.

2002. Food habits and consumption rates of common dolphinfish (Coryphaena hippurus) in the Eastern Pacific Ocean. Fish. Bull. 100:279-298.

Ortega-García, S., and S. Lluch-Cota.

1996. Distribución de la abundancia de atún aleta amarilla (Thunnus albacares) y su relación con la concentración de pigmentos fotosintéticos medidos por satélite en aguas al sur de México. Invest. Geogr. 4:85-93.

Oxenford, H. A.

1999. Biology of the dolphinfish (Coryphaena hippurus) in the western central Atlantic: a review. Sci. Mar. 63:277-301. Article

Palko, B. J., G. L. Beardsley, and W. J. Richards.

1982. Synopsis on the biological data of dolphin-fishes, Coryphaena hippurus Linnaeus and Coryphaena equiselis Linnaeus. NOAA Tech. Rep. NMFS. Circ. 443, 28 p.

Pantoja, D. A., S. G. Marinone, A. Parés-Sierra, and F. Gómez-Valdivia.

2012. Numerical modeling of seasonal and mesoscale hydrography and circulation in the Mexican Central Pacific. Cienc. Mar. 38:363-379.
Patterson, K. R., and J. Martinez.

1991. Explotation of the dolphin-fish Coryphaena hippurus. L. off Ecuador: analysis by length-based virtual population analysis. Fishbyte 9:21-23.

$\mathrm{R}$ Core Team.

2013. R: a language and environment for statistical computing. R Foundation for Statistical Computing. Vienna, Austria. [Available from website, accessed September 2013]

Reilly, S. B.

1990. Seasonal changes in distribution and habitat differences among dolphins in the eastern tropical Pacific. Mar. Ecol. Prog. Ser. 66:1-11.

Sakamoto, R., and S. Kojima.

1999. Review of dolphinfish biological and fishing data in Japanese waters. Sci. Mar. 63:375-385. Article

Santana-Hernández, H.

2001. Estructura de la comunidad de pelágicos mayores capturados con palangre en el Pacífico Mexicano (1983-1996) y su relación la temperatura superficial del mar. Ph.D. diss., 122 p. Univ. Colima, Manzanillo, Mexico.

Schwenke, K. L.

2004. Age, growth and reproduction of dolphin (Coryphaena hippurus) caught off the coast of North Carolina. M.S. thesis, 62 p. North Carolina State Univ., Raleigh, NC.

Sosa-Nishizaki, O.

1998. Historical review of the billfish management in the Mexican Pacific. Cienc. Mar. 24:95-111.

Theo, S., and L. B. A. Block.

2010. Comparative influence of ocean conditions on yellowfin and Atlantic bluefin tuna catch from longlines in the Gulf of Mexico. PLoS ONE 5:e10756. Article

Torres-Orozco, E.

1993. Analisis volumetrico de las masas de agua del Golfo de California. M.S. thesis, 92 p. Cent. Invest. Cient. Educ. Super. Ensenada. Ensenada, Mexico.

Tripp-Valdez, M. A.

2005. Ecología trófica del dorado Coryphaena hippurus (Linnaeus, 1758) en dos áreas del sur del Golfo de California. M.S. thesis, 125 p. Cent. Interdiscip. Cienc. Mar., Inst. Politéc. Nac., La Paz, Mexico.

Tripp-Valdez, M. A., F. J. García de León, S. Ortega-García, D. Lluch-Cota, J. López-Martínez, and P. Cruz.

2010. Population genetic structure of dolphinfish (Coryphaena hippurus) in the Gulf of California, using microsatellite loci. Fish. Res. 105:172-177. Article

Walsh, J. J., T. E. Whitledge, J. C. Kelley, S. A. Huntsman, and R. D. Pillsbury.

1977. Further transition states of Baja California upwelling ecosystem. Limnol. Oceanogr. 22:264-280. Article

Wang, C., and D. B. Enfield.

2001. The tropical Western Hemisphere warm pool. Geophys. Res. Lett. 28:1635-1638. Article

Zainuddin, M., H. Kiyofuji, K. Saitoh, and S. I. Saitoh.

2006. Using multi-sensor satellite remote sensing and catch data to detect ocean hot spots for albacore (Thunnus alalunga) in the northwestern North Pacific. Deep Sea Res., II 53:419-431. Article

Zaytzev, O., R. Cervantes-Duarte, O. Montanate, and A. Gallegos-García.

2003. Coastal upwelling activity on the Pacific shelf of the Baja California Peninsula. J. Oceanogr. 59:489-502. Article 
Zúñiga-Flores, M. S.

2009. Dinámica poblacional del dorado (Coryphaena hippurus) en Baja California Sur, México: implicaciones para su manejo. Ph.D. diss., 203 p. Cent. Interdiscip. Cienc. Mar., Inst. Politéc. Nac., La Paz, Mexico.

Zúñiga-Flores, M. S., S. Ortega-García and A. Klett-Trauslen. 2008. Interannual and seasonal variation of dolphinfish (Coryphaena hippurus) catch rates in the southern Gulf of California, Mexico. Fish. Res. 94:13-17. Article
Zúñiga-Flores, M. S., S. Ortega-García, M. D. C. RodríguezJaramillo, and J. López-Martínez.

2011. Reproductive dynamics of common dolphinfish Coryphaena hippurus in the Southern Gulf of California. Mar. Biol. Res. 7:677-689. Article

Zuur, A., E. N. Ieno, N. J. Walker, A. A. Saveliev, and G. M. Smith.

2009. Mixed effect models and extensions with R, 574 p. Springer-Verlag, New York. 